\title{
Species composition on reclaimed ski runs compared with unseeded areas
}

\author{
RON J. VAN OMMEREN
}

Author is a consulting biologist with Senna Environmental Services, Phoenix, Ariz. 85018. At the time of research, the author was a consulting biologist with SWCA, Inc. Environmental Consultants, Flagstaff, Ariz. 86001.

\begin{abstract}
The cover of native and non-native introduced plants was compared between seeded (reclaimed) ski runs and adjacent or nearby unseeded (control) areas at a managed ski area in northern Arizona to determine the potential effects of revegetation efforts on plant species composition of the area. Although vegetative cover was similar, plant species richness was significantly lower on reclaimed ski runs compared with control areas. At 3 of 4 sites, the number of plant species was more than 2-fold greater in control areas, although species richness was similar between control and reclaimed areas at 1 site. The proportion of native species was more than 3-fold greater in control areas compared with reclaimed ski runs. The proportion of non-native species was more than 5-fold greater on reclaimed ski runs than in control areas. Although sites differed substantially in time since seeding, no evidence was found at 3 of the 4 sites for either an invasion of non-native species into the native plant community, or significant re-establishment of native species in reclaimed areas. Relatively high biomass of native species on a reclaimed ski run at 1 site appeared to be tied to a low level of initial disturbance and favorable conditions for growth. Results suggested that minimizing initial soil disturbance, retaining topsoil, and maintaining islands or patches of natural vegetation within cleared areas promoted the re-establishment of native species on ski runs.
\end{abstract}

Key Words: disturbance, reclamation, ski runs, non-native species, richness

The use of native plant species in reclamation and revegetation projects has been advocated for a number of years, primarily because of concerns about potentially adverse impacts of nonindigenous species on native plant communities (Wade 1997, Baker 1995). Negative effects of non-native plant species cited include competitive exclusion of native species (Rosentreter 1992, Melgoza and Novak 1991, Aguirre and Johnson 1991, Young and Evans 1973, Harris 1967, Stewart and Hull 1949), contamination of native gene pools and loss of genetic diversity (Rosentreter 1992), increased fire frequency (Hughes et al. 1991,

Research was funded by the Arizona Snowbowl. I am grateful to the following persons for data collection and review of earlier versions of the manuscript: Arthur Phillips, Marilyn Murov, Dorothy House, Barbara Phillips, Tammy Randall-Parker, and J.R. Murray.

Manuscript accepted 21 Jul. 00.

\section{Resumen}

Se comparó la cobertura de plantas nativas e introducidas no nativas entre corredores de esquiar sembrados (rehabilitados) y en áreas adyacentes o cercanos sin sembrar (control) de un área de esquiar manejada del norte de Arizona. La comparación se realizó con el objetivo de determinar los efectos potenciales de los esfuerzos de revegetación en la composición de especies vegetales del área. Aunque la cobertura vegetal fue similar, la riqueza de especies fue significativamente menor en los corredores de esquiar que en las áreas control. En 3 de 4 sitios el número de especies vegetales fue 2 veces mayor en las áreas control, aunque en el sitio 1 la riqueza de especies fue similar entre las áreas control y las rehabilitadas. La proporción de especies nativas fue 3 veces mayor en las áreas control en comparación con los corredores de esquiar rehabilitados. En los corredores de esquiar rehabilitados la proporción de especies introducidas nonativas fue mas de 5 veces mayor que la de las áreas control. Aunque los sitios difirieron substancialmente en el tiempo en que fueron sembrados, en 3 de 4 sitios no se encontraron evidencias de la invasión de especies introducidas no nativas en las comunidades vegetales nativas ni del restablecimiento significativo de especies nativas en los corredores de esquiar. La biomasa relativamente alta de especies nativas en el corredor de esquiar del sitio 1 parece estar ligada a un bajo nivel inicial de disturbio y condiciones favorables para el crecimiento vegetal. Los resultados sugieren que minimizando el disturbio inicial del suelo, reteniendo la capa superficial del suelo y manteniendo islas o parches de vegetación nativa dentro de las áreas aclareadas para esquiar se promueve el restablecimiento de las especies nativas en los corredores de esquiar.

Rogers and Steele 1980, Beatley 1966), and change in soil characteristics (Kourtev et al. 1998).

From a management standpoint, the primary objective of revegetation of disturbed areas is soil stabilization. The construction and maintenance of ski runs on steep slopes requires erosion control measures to prevent soil loss. Although physical erosion control features, like berms, are often constructed, the re-establishment of vegetative groundcover is critical in reducing runoff and soil loss as it binds soils and increases infiltration rates (Andreu et al. 1995, Williams et al. 1995, Oliver and Larson 1990, Marks and Bormann 1972). Natural re-establishment of indigenous vegetation in disturbed areas may take years (Curtin 1995, Dyrness 1973), dictating the need for artificial seeding to re-establish vegetative groundcover quickly. In many instances, 
local cultivars for herbaceous plants and shrubs are not commercially available for a particular area. The need for immediate erosion control therefore often results in the use of a variety of species for reclamation, including commercially available cultivars of native species and species that have been introduced from other geographic regions.

The objective of this study was to determine the effects of reclamation on plant species composition on reclaimed (seeded) ski runs and on adjacent or nearby unseeded control areas in a managed ski area. The specific questions of interest were: 1) did native plants become re-established on reclaimed ski runs through time and 2) did non-native species invade adjacent natural areas and competitively exclude native species? To address these questions, we compared plant species composition between reclaimed areas with known seeding histories and adjacent or nearby control areas. We also studied the effects of time since seeding on the interaction between native and non-native species by comparing areas with varying times since seeding.

\section{Methods}

\section{Study Sites}

The study took place at the Arizona Snowbowl Ski Area on the western slopes of the San Francisco Peaks, an extinct volcanic cone located approximately $25 \mathrm{~km}$ northwest of Flagstaff, Ariz. U.S.A, at $35^{\circ}$ $19^{\prime} \mathrm{N}$ and $111^{\circ} 41^{\prime} \mathrm{W}$. Study sites were selected based on the presence of suitable unseeded control areas adjacent to or near reclaimed (seeded) areas to reduce potential within-site variability. Sites with different seeding histories were used in an attempt to examine the effects of length of time since seeding on plant species composition and cover.

Data were collected at 4 study sites, referred to as Southern Belle, Casino, Frontier, and Meadows. These study areas corresponded to the names of the existing ski runs and adjacent or nearby areas on which control plots were established. The Southern Belle site was at the lowest elevation (2,900-3,000 $\mathrm{m})$ and occurred within mixed-conifer habitat dominated by Douglas fir [Pseudotsuga menziesii (Mirb.)], Engelmann spruce [Picea engelmannii (Parry)], and limber and ponderosa pine [Pinus flexilis (James) and P. ponderosa (Lawson)]. Dominant herbaceous cover in forest openings and meadows included fescue [Festuca arizonica (Vasey) and F. ovina ( L.)], peavine

Table 1. Seed mixtures used during reclamation of the Southern Belle, Casino, and Frontier ski runs in 1984, 1985, and 1987-1988, respectively.

\begin{tabular}{|c|c|c|}
\hline Common Name & Scientific Name & Cultivar/Variety \\
\hline Timothy & Phleum pratense L. & 'Climax' \\
\hline Sheep fescue & Festuca ovina L. & $\mathrm{ns}^{1}$ \\
\hline Canada bluegrass & Poa compressa $\mathrm{L}$. & ns \\
\hline Mountain brome & Bromus marginatus Nees. & 'Bromar' \\
\hline Small burnet & Sanquisorba minor Scop. & 'Delar' \\
\hline Hairy vetch & Vicia villosa Roth & ns \\
\hline Birdsfoot trefoil & Lotus corniculatus L. & ns \\
\hline Clover & Trifolium hybridum L. & 'Alsike' \\
\hline Wooly pod vetch & Vicia dasycarpa Ten. & 'Lana vetch' \\
\hline
\end{tabular}

${ }^{1}$ Cultivar/variety not specified.

[Lathyrus arizonicus (Britton), sedges [Carex bella (Bailey) and C. wootonii (Mackenzie)], and mountain muhly [Muhlenbergia montana (Nutt.)].

The 3 other study sites (Casino, Frontier, and Meadows) occurred at higher elevations $(3,000-3,100 \mathrm{~m})$ in spruce-fir subalpine conifer forest dominated by Engelmann spruce, corkbark fir [Abies lasiocarpa var. arizonica (Merriam)], and bristlecone pine [Pinus aristata (Engelm.)]. Herbaceous cover in subalpine meadows and forest openings included brome [Bromus richardsonii (Link.)], sedges, peavine, avens [Geum turbinatum (Rydb.)], bluegrass and muttongrass [Poa pratensis (L.) and P. fendleriana (Steud.)], and muhly.

Southern Belle was reclaimed and seeded in 1984, Casino in 1985, Frontier in 1987 and 1988, and Meadows in 1993. An existing ski run, Tiger, was used as a control area for Casino. To the best of our knowledge, Tiger was never seeded and was used in the study because it was the only available control area for Casino. Seed mixtures used in each of these areas are summarized in Tables 1 and 2 .

\section{Vegetation Measurements}

Four measurement plots at each site were randomly established in reclaimed ski areas and adjacent or nearby unseeded control areas. Plots in reclaimed areas were placed near the center of ski runs. Control plots were established in adjacent or nearby nat-

Table 2. Seed mixture used during reclamation of the Meadows ski run in 1993.

\begin{tabular}{lll}
\hline \hline Common Name & Scientific Name & Cultivar/Variety \\
\hline Slender wheatgrass & Agropyron trachycaulum Link & 'Revenue' \\
Mountain brome & Bromus marginatus Nees. & 'Bromar' \\
Timothy & Phleum pratense L. & 'Climax' \\
Orchard grass & Dactylis glomerata L. & Pauite' \\
Sheep fescue & Festuca ovina L. & 'Covar' \\
Hard fescue & Festuca ovina L. & 'Durar' \\
Creeping red fescue & Festuca rubra L. & ns \\
Canada bluegrass & Poa compressa L. & 'Reubens' \\
Hairy vetch & Vicia villosa Roth & ns \\
\hline
\end{tabular}

ural or man-made openings, including a natural meadow (Southern Belle), natural forest openings (Meadows and Frontier), and a man-made unseeded ski run (Tiger). Areas where control plots were placed were generally similar in elevation, slope, aspect, and dimension (width) to reclaimed areas where plots were established (Table 3). Plots were located by initially establishing 4 parallel lines in both reclaimed and control areas, which were then subdivided to form 4 different rectangular quadrats. The upper right corner of each of four, $2 \mathrm{~m}^{2}$ plots established in the grid was determined at random using both line number and position along parallel lines within each quadrat.

Vegetation data were collected using the point-intercept method (Mueller-Dombois and Ellenberg 1974). A point-intercept frame was placed at $20 \mathrm{~cm}$ intervals on both sides of the $2 \mathrm{~m}^{2}$ plot centerline. Five points were measured along each frame placement by lowering guided pins and recording the plant species intercepted. When more than 1 species was intercepted, the species contributing most to the intercept was recorded. This technique yielded a total of 100 measurements per plot and allowed estimation of vegetative cover, plant species richness, and the proportion of native and non-native plants. Plants were identified to species in the field or later verified with herbarium specimens. All data were collected between 16 and 30 August 1996.

Data were analyzed for differences in 
Table 3. Characteristics of reclaimed (seeded) ski runs and adjacent or nearby unseeded control areas where four, $2 \mathrm{~m}^{2}$ plots were established and measured.

\begin{tabular}{lcccc}
\hline \hline Area & $\begin{array}{c}\text { Elevation } \\
(\mathrm{m})\end{array}$ & Aspect & $\begin{array}{c}\text { Slope } \\
(\%)\end{array}$ & $\begin{array}{c}\text { Width }^{1} \\
(\mathrm{~m})\end{array}$ \\
\hline $\begin{array}{l}\text { Southern Belle } \\
\text { Reclaimed }\end{array}$ & $2,970-3,030$ & W/SW & 22 & $45-60$ \\
Control & $2,990-3,030$ & SW & 20 & $80-230$ \\
Casino & & NW & 49 & $30-60$ \\
$\quad \begin{array}{l}\text { Reclaimed } \\
\text { Control }\end{array}$ & $3,140-3,250$ & NW & 47 & $20-45$ \\
$\begin{array}{l}\text { Frontier } \\
\text { Reclaimed }\end{array}$ & $3,000-3,140$ & & & $45-60$ \\
Control & $3,390-3,415$ & W/NW & 33 & $100-150$ \\
Meadows & $3,405-3,415$ & W & 44 & $25-35$ \\
$\quad \begin{array}{l}\text { Reclaimed } \\
\text { Control }\end{array}$ & $3,080-3,100$ & SW & 24 & $35-110$ \\
\hline
\end{tabular}

Estimated range of width of ski runs and adjacent or nearby control areas within which plots were established and measured.

vegetative cover and plant species richness, and differences in the proportion of native and non-native plants between reclaimed ski runs and adjacent or nearby unseeded control areas. Vegetative cover was estimated as the proportion of intercepts that contacted vegetation divided by the total number of possible intercepts (100), which included vegetation as well as bare ground, rock, and litter. Species richness was the total number of species recorded in each plot. For this analysis, native species were defined as those native to the San Francisco Peaks which were not found in the seed mixes. This distinction was made because it was not possible to determine the origin of species found in the field which were both native and which also occurred in the seed mix. These species were therefore conservatively included in the "non-native category". Two other classes of non-native species were also recognized, non-natives not found in either seed mix (origin unknown) and nonnatives found in one or both of the seed mixes (origin assumed to be from seed mix). The proportion of native species was expressed as the number of intercepts that contacted native vegetation divided by the total number of intercepts contacting vegetation, either native or non-native. The proportion of vegetative cover contributed by non-native species was calculated in the same fashion.

\section{Statistical Analyses}

A randomized block experimental design was used in this study. Two-way analysis of variance was used to determine whether vegetative cover, plant species richness, and the proportions of native and non-native plants differed consistently between reclaimed and control plots across sites. Each of the 4 sites represent- ed a block within which site conditions (elevation, slope, aspect, soils) and time since seeding of the treatment plots were relatively constant. At each site, 4 plots (replications) were measured in both the reclaimed and control areas. Data were analyzed for differences between "treatments" (reclaimed vs control) across sites and for overall differences among sites. All statistical analyses were performed using SAS (SAS Institute 1986). A Friedman rank test was used to verify results of parametric tests when there were significant $(\mathrm{p} \leq 0.05)$ departures from normality (Neter et al. 1990).

When significant $(\mathrm{p} \leq 0.05)$ differences were found among sites or treatment vs control plots, a Bonferroni or T-method test for multiple comparisons among pairs of means was used to determine differences among means (Sokal and Rohlf 1995, Neter et al. 1990). Because each site was seeded at a different time, data for each site were examined for trends through time.

The proportions of each type of nonnative species in reclaimed and control

Table 4. Mean vegetative cover in reclaimed (seeded) and adjacent or nearby unseeded control areas based on four, $2 \mathrm{~m}^{2}$ plots site treatment $^{-1}$ (32 plots total).

\begin{tabular}{lcccc}
\hline \hline \multicolumn{5}{c}{ Site } \\
\hline (yrs since seeding) & $\begin{array}{c}\text { Southern Belle } \\
(12)\end{array}$ & $\begin{array}{c}\text { Casino } \\
(11)\end{array}$ & $\begin{array}{c}\text { Frontier } \\
(9)\end{array}$ & $\begin{array}{c}\text { Meadows } \\
(3)\end{array}$ \\
\hline Reclaimed & 0.78 & 0.91 & 0.49 & 0.50 \\
Control & 0.89 & 0.83 & 0.69 & 0.64 \\
Combined & $0.83^{\mathrm{A}}$ & $0.87^{\mathrm{A}}$ & $0.55^{\mathrm{B}}$ & $0.57^{\mathrm{B}}$ \\
ANOVA & $\underline{\mathrm{df}}$ & $\underline{\mathrm{MS}}$ & $\underline{\mathrm{F}}$ & $\mathrm{p}$ \\
Sites & 3 & 0.22 & 17.73 & $<0.001$ \\
Treatments & 1 & 0.05 & 3.74 & 0.065 \\
Interaction & 3 & 0.02 & 1.75 & 0.18 \\
Error & 24 & 0.01 & - & - \\
\hline
\end{tabular}

T-method for multiple comparisons among means. Combined averages with same upper case letter within a row are not significantly different $(\mathrm{p} \leq 0.05)$. areas were analyzed separately using Wilcoxon Signed Rank tests for paired samples because of non-normally distributed data (Sokal and Rohlf 1995).

\section{Results and Discussion}

\section{Vegetative Cover}

Total vegetative cover was not significantly different between reclaimed and control areas. More recently reclaimed runs had less vegetative cover than runs with longer durations since seeding (Table 4). Southern Belle and Casino (seeded in 1984 and 1985, respectively) had significantly greater vegetative cover than Frontier and Meadows (seeded in 1987-88 and 1993, respectively), although cover was not significantly different between Southern Belle and Casino and between Frontier and Meadows.

Although an increase in vegetative cover over time was expected, these differences were not attributable to duration since seeding only. This was apparent because reclaimed areas with high vegetative cover also had high vegetative cover in associated control areas and vice versa, implicating other factors as well. Low vegetative cover at the Frontier site (seeded 9 years prior) may have resulted from high elevation, steep slopes, and a high degree of exposure to wind and direct sun. Lower vegetative cover at the Meadows site compared with the Southern Belle site, both of which occurred at similar elevations and had similar aspects and slopes, likely resulted from less time since seeding (Meadows was seeded 3 years prior, Southern Belle 12 years prior). Casino, the site with the highest vegetative cover, was seeded 11 years earlier and faces northwest, in the lee of prevailing southwest winter winds. Coupled with indirect winter sun, this allowed snow to accumulate 
Table 5. Mean species richness in reclaimed (seeded) and adjacent or nearby unseeded control areas based on four, $2 \mathrm{~m}^{2}$ plots site treatment $^{-1}$ (32 plots total).

\begin{tabular}{|c|c|c|c|c|}
\hline \multicolumn{5}{|c|}{ Site } \\
\hline (yrs since seeding) & $\begin{array}{l}\text { Southern Belle } \\
\text { (12) }\end{array}$ & $\begin{array}{l}\text { Casino } \\
\text { (11) }\end{array}$ & $\begin{array}{l}\text { Frontier } \\
\text { (9) }\end{array}$ & $\begin{array}{l}\text { Meadows } \\
\text { (3) }\end{array}$ \\
\hline Reclaimed $^{1}$ & $4.0^{\mathrm{a}}$ & $9.8^{\mathrm{a}}$ & $5.5^{\mathrm{a}}$ & $5.3^{\mathrm{a}}$ \\
\hline Control & $9.0^{\mathrm{b}}$ & $9.0^{\mathrm{a}}$ & $12.0^{\mathrm{b}}$ & $12.5^{\mathrm{a}}$ \\
\hline Combined & 6.5 & 9.4 & 8.8 & 8.9 \\
\hline${\underline{\text { ANOVA }^{2}}}^{2}$ & $\underline{\mathrm{df}}$ & $\underline{\mathrm{MS}}$ & $\underline{F}$ & $\mathrm{p}$ \\
\hline Sites & $\overline{3}$ & 13.08 & $\overline{2} .05$ & 0.13 \\
\hline Treatments & 1 & 16.20 & 25.33 & $<0.001$ \\
\hline Interaction & 3 & 26.25 & 4.10 & 0.0174 \\
\hline Error & 24 & 6.40 & 一 & 一 \\
\hline
\end{tabular}

${ }^{\mathrm{T}}$ Significant differences between reclaimed and control plots within sites were tested using a Bonferroni multiple comparison procedure with a family confidence coefficient of 0.95 .

Averages with the same lower case letters within a column are not significantly different $(\mathrm{p} \leq 0.05)$

2 Data were non-normally distributed; results of the ANOVA were verified with a non-parametric Friedman rank test. through the winter, making the site more mesic. Furthermore, surface disturbance during construction was much less severe than at any of the other sites, preserving the topsoil, seedbank, and microsites favorable for plant establishment.

\section{Plant Species Richness}

Plant species richness was generally greater in control areas compared with reclaimed areas (Table 5). The total number of plant species was nearly 2 -fold greater for control plots than plots in reclaimed areas over all sites studied. However, a significant interaction occurred between sites and treatments within sites, indicating that greater species richness in control areas was not consistent across all sites. At the Casino site, plots in the reclaimed area had similar richness as control plots. However, at the 3 remaining sites (Southern Belle, Frontier, Meadows), species richness was more than 2-fold greater for control plots as compared with reclaimed areas. No relationship could be found between duration since seeding, represented by different sites, and species richness.

Lower plant species richness in reclaimed areas at all sites except Casino was primarily attributable to lack of reestablishment of native species. Species composition consisted primarily of nonnative, seed-mix species in reclaimed areas and native species in control areas. Greater species richness in reclaimed areas at Casino likely resulted from a number of factors, including site characteristics such as slope and aspect, and favorable soil moisture conditions. Perhaps the most important factor was the minimal amount of substrate disturbance that occurred during construction of this run, which likely preserved the native seedbank and soil profiles. Overall, no clear pattern was found in relation to time since seeding, and it appeared that natural and manipulated site factors were of primary importance in determining species richness in revegetated areas.

\section{Distribution and Frequency of Native and Non-native Plants}

As expected, the proportion of native species was greater in control areas and the proportion of non-native species was greater in reclaimed areas (Table 6). Across all sites studied, the proportion of native species was more than 3 -fold greater in control areas compared with reclaimed areas. The proportion of nonnative species was more than 5-fold greater in reclaimed compared with control areas. The interaction between sites and treatments within sites was significant, which indicated that differences in the proportion of native vs non-native species varied significantly among some of the sites. At Casino, the proportion of native plants in control plots was about $27 \%$ higher than that in reseeded plots. In contrast, the proportion of native plants in control plots was from about 5-fold to nearly 20-fold higher than that of plots in reclaimed areas at the 3 other sites.

Some differences were found between reclaimed and control areas in the frequency of occurrence for different types of non-native species. There were no differences between reclaimed and control areas in the proportion of native species that were also found in one of the seed mixes (conservatively included as a "non-native" category, Wilcoxon sign rank, $\mathrm{z}=-0.91, \mathrm{p}$ $=0.18$ ) or in the proportion of species not indigenous to the study area and also not found in the seed mixes (origin unknown, Wilcoxon sign rank, $\mathrm{z}=-0.55, \mathrm{p}=0.71$ ). However, species not native to the San Francisco Peaks that were found in one or both of the seed mixes made up a significantly higher proportion of the vegetation in reclaimed areas compared with control areas (Wilcoxon sign rank, $\mathrm{z}=-1.64, \mathrm{p}=$ 0.05). At control areas, these species were found only at the Casino site, where they made up slightly more than $2 \%$ of the vegetative cover. These species were not recorded at the 3 other sites. Of the 3 categories of non-native species analyzed, only the presence of this category of species could be reliably attributed to prior seeding.

No relationship between time since seeding and the proportion of native and non-native species was apparent. In reclaimed areas, the greatest proportion of the vegetative cover contributed by native species occurred at Casino (seeded in 1985), followed by Meadows (seeded in 1993), Southern Belle (seeded in 1984), and Frontier (seeded in 1987-88) (Table
Table 6. Mean proportion of native species out of all intercepts contacting vegetation (native and non-native species) within plots in reclaimed (seeded) and unseeded control areas, based on four, $2 \mathrm{~m}^{2}$ plots site treatment $^{-1}$ (32 plots total).

\begin{tabular}{|c|c|c|c|c|}
\hline \multicolumn{5}{|c|}{ Site } \\
\hline (yrs since seeding) & $\begin{array}{c}\text { Southern Belle } \\
\text { (12) }\end{array}$ & $\begin{array}{c}\text { Casino } \\
\text { (11) }\end{array}$ & $\begin{array}{c}\text { Frontier } \\
\text { (9) }\end{array}$ & $\begin{array}{c}\text { Meadows } \\
\text { (3) }\end{array}$ \\
\hline $\begin{array}{l}\text { Reclaimed }^{1} \\
\text { Control } \\
\text { Combined }^{2}\end{array}$ & $\begin{array}{l}0.09^{\mathrm{a}} \\
0.96^{\mathrm{b}} \\
0.52^{\mathrm{B}}\end{array}$ & $\begin{array}{l}0.74^{\mathrm{a}} \\
0.95^{\mathrm{b}} \\
0.85^{\mathrm{A}}\end{array}$ & $\begin{array}{l}0.06^{\mathrm{a}} \\
0.90^{\mathrm{b}} \\
0.48^{\mathrm{B}}\end{array}$ & $\begin{array}{l}0.14^{\mathrm{a}} \\
0.68^{\mathrm{b}} \\
0.41^{\mathrm{B}}\end{array}$ \\
\hline$\underline{\text { ANOVA }}$ & $\underline{\mathrm{df}}$ & $\underline{\mathrm{MS}}$ & $\underline{\mathrm{F}}$ & $\underline{p}$ \\
\hline Sites & 3 & 0.30 & 29.18 & $<0.001$ \\
\hline Treatments & 1 & 3.038 & 295.38 & $<<0.001$ \\
\hline Interaction & 3 & 0.20 & 18.97 & $<<0.001$ \\
\hline Error & 24 & 0.0103 & - & - \\
\hline
\end{tabular}

Significant differences between reclaimed and control plots within sites were tested using a Bonferroni multiple comparison procedure with a family confidence coefficient of 0.95 . Averages with the same lower case letters within a column (first 2 rows only) are not significant at $\mathrm{p} \leq 0.05$.

${ }^{2} \mathrm{~T}$-method for multiple comparisons among means. Combined averages with same upper case letter (within the row) are not significantly different $(\mathrm{p} \leq 0.05)$. 
6). The opposite relationship held for nonnative species.

These data suggest neither re-establishment of native species on ski runs over time, nor invasion of adjacent unseeded areas by non-native species occurred. At Frontier, Meadows, and Southern Belle, plant species composition was very distinct between the reclaimed areas, which supported primarily non-native species, and control areas, which supported an entirely native plant community. Differences in plant species composition were less distinct between reclaimed and control plots at the Casino site. This result was likely due to minimal initial disturbance, which preserved soil conditions, microsites, and a predominantly native seedbank.

Similar results have been obtained by other researchers. An assessment of 4 ski areas in Colorado showed that ski slopes were covered with seeded species and largely devoid of indigenous species. There was also no indication that the seeded species were invading adjacent undisturbed habitats (Redner, N., unpublished monitoring report. USDA For. Serv., Silverthorne, Colo., 13 September 1994). Curtin (1995) concluded that disturbed subalpine plant communities in Colorado remained distinct in species composition, richness, and cover from surrounding undisturbed areas for hundreds of years. Disturbed sites, some abandoned over 100 years ago, were still covered with monotypic stands of exotic grasses and weedy species. In the Cascades in Oregon, Dyrness (1973) found that logged and lightly burned sites regained dominance by predisturbance native plants within 5 years, while severely burned sites continued to be dominated by invasive species. Since native plant regeneration after disturbance occurs primarily through germination of buried seeds and vegetative propagation (Whittle et al. 1997), protection of seed banks and minimized surface disturbance during construction activities should promote the conservation of native plant communities.

\section{Literature Cited}

Aguirre, L. and D.A. Johnson. 1991. Influence of temperature and cheatgrass competition on seedling development of two bunchgrasses. J. Range Manage. 44: 347-354.

Andreu, V., J.L. Rubio, and R. Cerni. 1995. Effect of Mediterranean shrub on water erosion control. Envir. Monitoring and Assessment. 37: 5-15.
Baker, M.A. 1995. Recommendations for the preservation of rare plants and unique habitats within the Chino Valley Ranger District, Central Arizona, p. 237-242. In: J. Maschinski, D.H. Hammond, and L. Holter (eds), Southwestern Rare and Endangered Plants: Proc. 2nd Conference, Flagstaff, Ariz. USDA For. Serv. Rocky Mtn. For. Range Exp. Sta. Gen. Tech. Rep. RM-GTR-283.

Beatly, J.C. 1966. Ecological status of introduced brome grasses (Bromus spp.) in desert vegetation in southern Nevada. Ecol. 47: 548-554.

Curtin, C.G. 1995. Can montane landscapes recover from human disturbance? Long-term evidence from disturbed subalpine communities. Bio. Conserv. 74: 49-55.

Dyrness, C.T. 1973. Early stages of plant succession following logging and burning in the western Cascades of Oregon. Ecol. 54:57-68.

Harris, G.A. 1967. Some competitive relationships between Agropyron spicatum and Bromus tectorum. Ecol. Monogr. 37: 89-111.

Hughes, F., P.M. Vitousek, and T. Tunison. 1991. Alien grass invasion and fire in the seasonal submontane zone of Hawai'i. Ecol. 72:743-746.

Kourtev, P.S., J.G. Ehrenfeld, and W.Z. Huang. 1998. Effects of exotic plant species on soil properties in hardwood forests of New Jersey. Water, Air, and Soil Pollution 105:493-501.

Marks, P.L. and F.H. Bormann. 1972. Revegetation following forest cutting: mechanisms for return to steady-state nutrient cycling. Sci. 176:914-915.

Melgoza, G. and R.S. Nowak. 1991. Competition between cheatgrass and two native species after fire: implications from observations and measurement of root distribution. J. Range Manage. 44:27-33.

Mueller-Dombois, D. and H. Ellenberg. 1974. The point-intercept method, p.84-89. In: Aims and methods of vegetation ecology. John Wiley and Sons, New York, N.Y.

Neter, J., W. Wasserman, and M.H. Kutner. 1990. Applied linear statistical models. 3rd edition. Irwin Press, Boston, Mass.

Oliver, C.D. and B.C. Larson. 1990. Disturbances and stand development. pp. 109-110. In: Forest stand dynamics. McGraw-Hill, New York, N.Y.

Rogers G.F. and J. Steele. 1980. Sonoran desert fire ecology, p. 15-19. In: USDA For. Serv. Tech. Rep. RM-81.

Rosentreter, R. 1992. Displacement of rare plants by exotic grasses. In: Proceedings of the Symposium on Ecological Management and Restoration of Intermountain Annual Rangelands, Boise, Ida.

SAS Institute. 1986. SAS User's Guide, Version 6.02. SAS Institute, Raleigh, N.C.

Sokal, R.R. and F.J. Rohlf. 1995. Biometry. 3rd edition. W.H. Freeman and Company, New York, N.Y.

Stewart, G. and A.C. Hull. 1949. Cheatgrass (Bromus tectorum)—An ecologic intruder in southern Idaho. Ecol. 30:58-74.

Wade, M. 1997. Predicting plant invasions: making a start. p. 1-18. In: J.H. Brock (ed),
Plant invasions: studies from North America and Europe. Backhuys Publishers, Leiden, Netherlands.

Whittle, C.A., L.C. Duchesne, and T. Needham. 1997. The importance of buried seeds and vegetative propagation in the development of postfire plant communities. Envir. Rev. 5: 79-87.

Williams, A.G, L. J. Ternan, A. Elmes, M.G. Del Tanago, and R. Blanco. 1995. A field study of the influence of land management and soil properties on runoff and soil loss in central Spain. Envir. Monitoring and Assessment 37:333-345.

Young, J.A. and R.A. Evans. 1973. Downy brome - Intruder in the plant succession of big sagebrush communities in the Great Basin. J. Range Manage. 26: 410-415. 